\title{
MODIFICATION OF SEMI-AUTOMATIC TRANSPLANTER FOR COTTON SEEDLINGS
}

\section{El-Yamani, A.E*; M.A. Khodeir* and M.A. Hassan* \\ BASTRACT}

The experiments were carried out during 2014 seasons at Sakha-farm research to evaluate performance of modification transplanter for cotton seedling. The experiments were conducted using a modification transplanter to evaluate the effect of forward speed of 1.88, 2.35, 2.95 and $3.38 \mathrm{~km} / \mathrm{h}$, hill spacing of $0.15,0.2,0.25$ and $0.3 \mathrm{~m}$ and planting depth of $8,10,12,15 \mathrm{~cm}$. the present work was used to study the effect of previous variables on effective field capacity, field efficiency, longitudinal and transverse seed scattering, ground wheel slip, germination ratio, seedling miss index, the seedlings multiples index, the quality of feed index, the amount of seedling rate and crop yield. Also, determination of specific fuel consumption, operating and criterion function cost of cotton transplanting were done. Results illustrated that by increasing planting forward speed actual field capacity, affective field efficiency, both of longitudinal and transverse scattering, slip ratio, seedling miss index, the quality of feed index and criterion function cost were increased. While, seedling multiple index, specific fuel consumption, productivity and total operation cost were decreased. Maximum of effective field capacity, field efficiency, productivity, specific fuel consumption and the quality of feed index were $0.739 \mathrm{fed} / \mathrm{h}$, $83.1 \%, 7.61$ kantar/fed, $0.731 \mathrm{~L} / \mathrm{kW} . \mathrm{h}$ and $92.3 \%$ respectively. While, minimum of longitudinal scattering, transverse scattering, slip ratio, seedling miss index was and seedling multiple index were $0.016 \mathrm{~m}, 0.010$ $m, 7.42 \%, 2.1 \%$ and $4.0 \%$ respectively. The optimum operation condition of machine transplanting was obtained at forward speed of $2.95 \mathrm{~km} / \mathrm{h}$, hill spacing of $0.25 \mathrm{~m}$ and planting depth of $8 \mathrm{~cm}$.

Keywords: cotton transplanted, seedling scattering, seedling miss index, the seedlings multiples index, the quality of feed index, specific fuel consumption, operating and criterion function cost of cotton transplanting.

\footnotetext{
*Ag. Eng. Res. Inst., (AEnRI) Giza, Egypt.
} 


\section{INTRODUCTION}

$\mathrm{E}$ gyptian cotton crop seedlings grown in a way given the tremendous results excelled at everything on cotton seed and grown with its features helped solve many problems afflicting the most important of Egyptian cotton intense competition faced by other crops, as the relative increase in the cost of cotton production to switch to more profitable crops. Cotton seedlings have many advantages: shorten the growing season to provide cotton or reduce the cost of production; possibility of cultivation of cotton after winter crops in the same space; providing cottonseed and maintain the purity of the product; the production of hybrid cotton; reduce the proportion of early and late injuries; leads to the genie once saving in the cost of production in the plant age; increased durability cotton output and increase the amount of production. The advantages of mechanical transplanting are place seeding more uniform than manual transplanting. The uniformity of placing seedlings by the mechanical transplanting attributed to the transplanting mechanism design more than the operation condition. Ground speed of $0.9 \mathrm{~km} / \mathrm{h}$ was suitable for operating the mechanical transplanting (Harb et al., 1993). ASAE (1989) reported that the field efficiency decreased by increasing forward speed, so the field efficiency is the ratio of the productivity of a machine under field conditions to the theoretical maximum productivity. El-Sayed (1992) studied the effect of transplanting on growth and yield of cotton. He found that the first node carrying fruiting branches was high for direct sowing and low for transplanting method. Salama et al. (1995) found that the mechanical transplanting had a highly effect on fruit weight and number of fruits per plant compared with manual transplanting. El-Fowal (1996) studied the effect of transplanting forward speed on slippage and field efficiency his results indicated that the slippage values were of $16.49,16.84$ and 10.82 and $11.85 \%$ and the field efficiency values were $75.64,74.72$ and 58.11, $59.64 \%$ at $1.22,1.26$ and $1.51,1.44 \mathrm{~km} / \mathrm{h}$ transplanting forward speed, respectively for 4-row walking and 6-row riding transplanter. Hammed et al. (1993) said that seedling damage in planting and feeding losses increased due to increasing transplanter forward speed. El-Sahrigi et al.(1991) indicated that the mechanical sowing and transplanting have 
lower cost than hand sowing or transplanting. The cost of manual transplanting of onion seedlings was 1.52 times higher than that when using transplanting machine. Also, it was about 2 times higher than when using 3-row transplanting machine and 2.22 times larger than that when using 5-row transplanting machine. They concluded that using mechanical sowing or transplanting methods is recommended for obtaining high yield and minimizing cost. Konosuke TSUGA (2000) developed three models of riding-type, fully automatic vegetable transplanters. These prototypes were suitable for cell mold seedlings and pulp mold cell pot seedlings. The prototypes enabled continuous transplanting work on two rows simultaneously, a planting speed of 60 cells/row/min, with vegetable seedlings fed automatically. The transplanting accuracy, in terms of the rate of implanted hills, was 3\% or less, and the working capacity per worker was approximately $10 \mathrm{a} / \mathrm{h}$. The minimum economically suitable area for use was 8.2 ha. Seedling transplanting can significantly increase yield, reduce seeding rates and improve crop establishment by eliminating harmful environmental effects before transplanting. For cotton, the duration of growth and development was extended in comparison with normal planting methods (Dong et al., 2005). Such advantages for cotton transplanting have also been demonstrated in other countries (Sherif et al., 1995; El-Sahrigi et al., 2001; Greer et al., 2003; Karve, 2003; Sales et al., 2006). Hassan et al., (2006) found that all the studied traits fiber length, uniformity ratio, micronaire reading and fiber strength showed highly significant difference mean squares for genotypes, environments and the interaction between them. They added, that the genotypes grown in Kafr El-Sheikh region (G45, G70, G87 and G88) gave the highest values for most traits. Collecting data for many genotypes over different locations and analyze them statistically. The objective of the present work was modified the vegetable transplanter to suit the cotton seedling and evaluate its performance comparing with manual cotton seedling for hybrid seed production.

\section{MATERIALS AND METHODS}

This research was conducted at Sakha-farm research, Kafr el-Sheikh Governorate in 2014 to evaluate the field performance of Holland type 
transplanter under local conditions. The field was prepared by using 7 blades chisel plough twice and used hydraulic scraper to level and creates an ultimate smooth surface. Yanemar tractor $29 \mathrm{hp}(21.3 \mathrm{~kW})$ was used to mount the chisel plow, scraper and cotton seed planting transplanting machine. All Agricultural operations such as fertilizing, irrigation and pest control were performed in a similar manner to that commonly practiced at the Egyptian farms. The mechanical analysis data of the experimental soil are shown in Table1. Cotton seed variety of Giza 88 was sown in 1st May 2014. The spacing between rows was fixed at 0.76 $\mathrm{m}$. The seedling was planted in paper pot sets.

Table1: Some mechanical analysis of soil .

\begin{tabular}{|c|c|c|c|}
\hline \multicolumn{3}{|c|}{ Particle size distribution } & \multirow{2}{*}{ Soil type } \\
\hline Clay, $\%$ & Silt, $\%$ & Sand, $\%$ & \\
\hline 54 & 25 & 21 & Clay loam \\
\hline
\end{tabular}

Holland type transplanter before developments:

The available transplanter is an American made transplanter. It is semiautomatic transplanter made up of two units and intended for transplanting of ball seedlings on well-prepared fields and used in the cultivation of seedlings of various vegetables. The cross section machine and its specifications are shown in Fig. 1 and Table 2. The Holland transplanter components are: furrow opener, pocket for plants, packing wheels and plant boxes. These parts are mounted onto a common frame attached to the three point hitch toolbar. Plants are placed manually onto the transplanting pockets that consist of two rubber plates in order to hold the plant. The rubber plates are opened and closed by using a special spring mechanism. The closing of the rubber occur as soon as the pocket enters two guide plates which compress the spring. When the pocket passes from the guide plates, the spring pressure is released,

Table 2: The specifications of the Holland transplanter.

\begin{tabular}{|l|l|}
\hline Specifications & Holland transplanter \\
\hline Manufacture & U.S.A \\
Model & Holland type 1600 \\
Total length, $\mathrm{m}$. & 1.30 \\
Total width, $\mathrm{m}$. & 1.45 \\
Total height, $\mathrm{m}$. & 0.95 \\
Total mass, $\mathrm{kg}$. & 120 \\
Hitching type & 3 point \\
Number of units & 1 \\
\hline
\end{tabular}


loosening the rubber plates and releasing the plant to slip from pocket and remain it in the soil.

\section{Holland type transplanter after developments:}

Suggested modification and Proposed improvements to the machine:

Some modifications to fit the seedlings cotton cultivation was done to vegetable seedlings semi-automatic units the cotton seeds were planted in pots and paper with the dimensions of $4 \times 5 \mathrm{~cm}$ filled with soil and good fertilizer needed for germination and they are nurtured until it reaches a length of about $10 \mathrm{~cm}$. The improved planting transplanted machine and cross- section in feeding system and its components were shown in Fig.

2. The principal improvements made to the machine were as follows:-

1- Modified feed system of seedling supply system, skip to the feeding chain system and installed on the round about surrounding the number 20 , holder of the seedlings.

2- Half rotor feeding chain is in an upright position and surrounded by a lid to prevent the fall of the seedlings before they arrive to the ground of sustainable agriculture and the other half will be in a horizontal position on the pallet spins allows the operator to feed seedling holder with great precision and ease.

3- Gearbox used in the transmission of the ground wheel to another gear on the horizontal pallet used for driving feeding chain.

4- Seedlings are fed on a pallet feeding so that the seedling in a horizontal position and be the root to the outside and with the rotation, the root is falling to the place of permanent agriculture to the bottom and the status of the plant regularly.

The machine works on the principle of dropping-potted plants from a certain height to the ground. The impact of the seedling with soil block helps in its placement. The unit consists of main frame with hitching system, ground wheel, shoe type, furrow openers, compaction wheel, operators seat, plug type metering mechanism and two depth control wheels. It employs press wheels inclined at an angle of $15^{\circ}$ with the vertical as soil covering device.

\section{Investigated variables:}

The present study was included the following:- 
1-Modified transplanter forward speed : four forward speeds were used $1.88,2.35,2.95$ and $3.38 \mathrm{~km} / \mathrm{h}$, where it is controlled by the speed of the machine transplanting by adjusting the fuel consumption rate of the tractor.

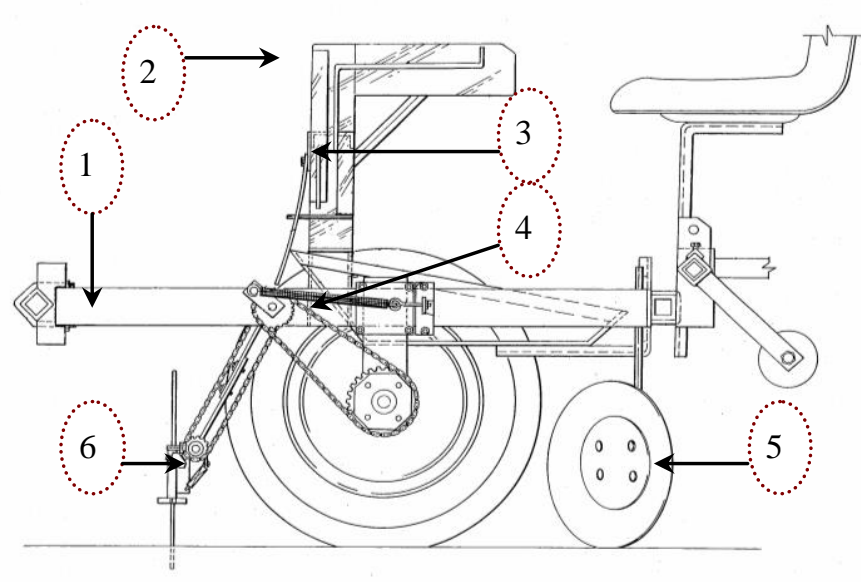

Fig.1: A geometrical drawing of a semi-automatic transplanter before modification, 1) Main frame 2) Planting hopper 3) Seedlings tube 4) Plug type metering mechanism 5) Compaction wheel 6) Furrow openers 7)seat.

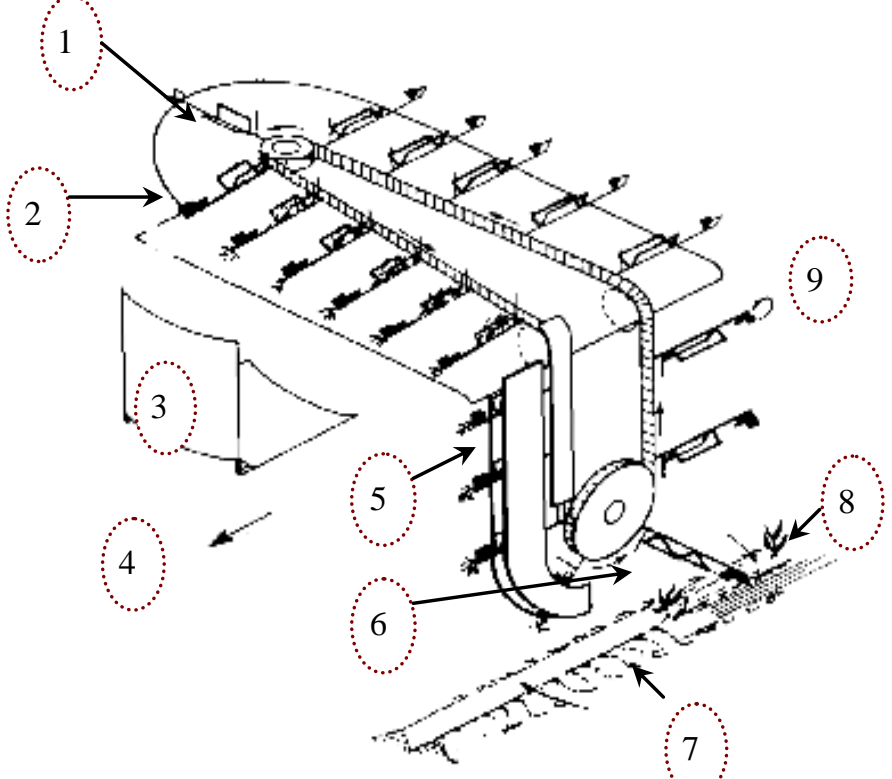

Fig.2: Geometrical drawing of a multiple loading station transplanter utilizing chain mounted clip which stores and plants seedling without transfer(after modification), 1)table 2)clips loaded 3) seat 4) direction of travel 5) clips closed 6) clip opened 7) furrow open 8)furrow closed 9) clip rotated up right. 
2- Hill spacing: four different of hill spacing were used in the present work $0.15,0.2,0.25$ and $0.3 \mathrm{~m}$, where the distances are adjust by controlling the rotational speed of the transfer mat seedling transplanting machine.

3- Seedling depth: four seedling depth were used 8, 10, 12, $15 \mathrm{~cm}$, where seedling depth was controlled by adjusting the transplanting divider depth to open of the soil.

\section{Measurements:}

\section{1-Effective field capacity ( EFC) and field efficiency:}

Field capacity were determined according to the following equations:

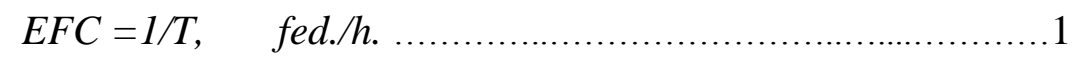

Where:

$\mathrm{T}=$ Effective planting time, $\mathrm{h}$.

Field efficiency was calculated by the following formula:

$$
\text { Field efficiency, } \%=\frac{\text { Effective field capacity }(f e d / h)}{\text { Theoretical field capacity }(f e d / h)} \times 100 \quad \ldots 2
$$

\section{2-Seedling scattering:}

The seedling longitudinal and transverse scattering was calculated according to the following formula (Stell and Torrie, 1980):

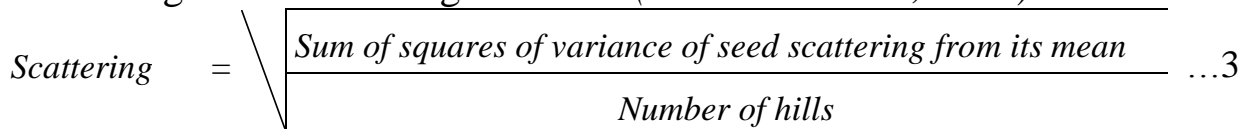

\section{3-Ground wheel slip:}

Slippage percentage was calculated by using the following equation (Awady, 1992).

$$
\text { Slip } \%=\frac{\text { distance without load }- \text { distance with load. }}{\text { distance with load. }} \times 100
$$

\section{4- Seedling Miss Index (Sm, \%) :}

The seedling miss index could be considered as the seedling disposing performance. It was estimated for each treatment by counting the number of location that have no seedlings and counting the total number of the seedling in each treatment. Then the percentage of miss index can be calculated as follows (Srivastava, 1994):

$$
\text { Sm, } \%=\frac{B n \times 100}{M}
$$


Where:

$\mathrm{Sm}=$ the percentage of seedling miss index, $\%$

$\mathrm{M}=$ the total number of the used seedling.

$\mathrm{Bn}=$ the number of seed location that have no seedling.

\section{5- The seedlings multiples index, (Smu \%)}

The seedling double ratio could be considered as the second indicator for the seedling disposing performance. It was estimated for each treatment by counting the number of holes that have more than one seedling and counting the number of the total seedling in each treatment. Then the percentage of seedlings multiples index can be calculated as follows:

$$
\text { Smu, } \%=\frac{A n \times 100}{M} \cdots \ldots \ldots \ldots .6
$$

Where:

Smu, $\%=$ the percentage of seedlings multiples index, $\%$

$\mathrm{An}=$ the number of holes that have more than one seedlings.

\section{6- The quality of feed index (UH, \%)}

The uniformity of the seedling in row could be considered as the third indicator for the seed disposing performance. It was estimated by calculating the seed miss index and the seed multiples index. Then the percentage of the quality of feed index in row can be calculated as follows:

$U H, \%=100-(S m, \%+S m u, \%)$.

\section{7- Productivity :}

The cotton crop yield was determined for manual and mechanical transplanted, A number of samples a long the row were taken from different locations for each treatment at random, and then weighted and integrated to determine the average yield of cotton per feddan .

\section{8-Calculation of specific fuel consumption (S.F.C):}

The specific fuel consumption was calculated using the following formula (Suliman et al., 1993).

$$
\text { S.F.C }=\frac{\text { Fuel consumption, } l / h}{\text { Power consumed, } k W}, \quad L / K w \cdot h
$$

\section{9- Total cost requirements:}

The total cost need for operation was estimated by the following formula (Hunt, 1983): 
Operating cost $=\frac{\text { Machine cost }, \text { L.E } / \text { h }}{\text { Yield output }, \text { ton } / \mathrm{h}}, \quad$ L.E/ton ............. 9

Here, machine cost was determined by the following formula (Hunt, 1983): $\quad C=p / h(1 / a+i / 2+t+r)+(0.9$ w.s.f $)+m / 144 \ldots \ldots \ldots \ldots \ldots . .10$ Where:

$$
\begin{array}{llll}
\mathrm{C} & =\text { hourly cost, L.E/h. } & 0.9 & =\text { factor accounting for lubrication } \\
\mathrm{p} & =\text { price of machine }, \text { L.E. } & \mathrm{w} & =\text { engine power, hp } \\
\mathrm{a} & =\text { life expectancy of the machine, } \mathrm{h} . & \mathrm{s} & =\text { specific fuel consumption, } \mathrm{l} / \mathrm{hp} . \mathrm{h} . \\
\mathrm{h} & =\text { yearly working hours, h/year. } & \mathrm{r} & =\text { repairs and maintenance ratio. } \\
\mathrm{i} & =\text { Interest, rate/year. } & \mathrm{m} & =\text { monthly average wage, L.E. } \\
\mathrm{t} & =\text { taxes ratio } & \mathrm{f} & =\text { fuel price, } \mathrm{L} . \mathrm{E} / \mathrm{l}
\end{array}
$$

$144=$ reasonable estimation of monthly working hours.

Also, criterion function cost, L.E/ton= operating cost, L.E/ton+ losses cost, L.E/ton ....11

\section{RESULTS AND DISCUSSION}

\section{Preliminary trial( before modification):}

Initial experiment was carried out at transplanting seedling cotton crop variety of Giza 88 during 2013 by using Holland transplanter to determine the effect of forward speed, planting depth on effective field capacity, seedling miss index, seedling multiple index and quality of feed index. Obtained results are presented in Table 3.

Table 3: Transplanting machine performance before modification.

\begin{tabular}{|c|c|c|c|c|c|c|c|c|c|c|c|c|}
\hline & \multicolumn{1}{|c|}{$\begin{array}{c}\text { Effective field } \\
\text { capacity, fed/h }\end{array}$} & \multicolumn{1}{c|}{$\begin{array}{c}\text { Seedling miss } \\
\text { index, \% }\end{array}$} & \multicolumn{3}{|c|}{$\begin{array}{c}\text { Seedling } \\
\text { multiple } \\
\text { index, \% }\end{array}$} & \multicolumn{3}{|c|}{$\begin{array}{c}\text { Quality of feed } \\
\text { index, \% }\end{array}$} \\
\hline $\begin{array}{c}\text { Planting } \\
\text { depth, } \\
\text { cm }\end{array}$ & $\mathbf{2 . 3 5}$ & $\mathbf{2 . 9 5}$ & $\mathbf{3 . 3 8}$ & $\mathbf{2 . 3 5}$ & $\mathbf{2 . 9 5}$ & $\mathbf{3 . 3 8}$ & $\mathbf{2 . 3 5}$ & $\mathbf{2 . 9 5}$ & $\mathbf{3 . 3 8}$ & $\mathbf{2 . 3 5}$ & $\mathbf{2 . 9 5}$ & $\mathbf{3 . 3 8}$ \\
\hline $\mathbf{8}$ & 0.54 & 0.59 & 0.66 & 9.5 & 11.3 & 12.2 & 5.9 & 7.1 & 9.8 & 84.6 & 81.6 & 78 \\
\hline $\mathbf{1 2}$ & 0.49 & 0.56 & 0.63 & 10.3 & 12.5 & 13.4 & 7.8 & 8.9 & 12.2 & 81.9 & 78.6 & 74.4 \\
\hline $\mathbf{1 5}$ & 0.45 & 0.53 & 0.59 & 11.5 & 14.1 & 17.9 & 9.2 & 12.6 & 15 & 79.3 & 73.3 & 67.1 \\
\hline
\end{tabular}

\section{b) Performance of transplanting machine( after modification) :-}

\section{Effective field capacity}

Effective field capacity increased as forward speed, hill spacing and planting depth increased as shown in Fig. 3. Results noticed that, maximum effective field capacity was about $0.748 \mathrm{fed} / \mathrm{h}$. was recorded at 
forward speed of $3.38 \mathrm{~km} / \mathrm{h}$, hill spacing of $0.3 \mathrm{~m}$ and planting depth of 8 $\mathrm{cm}$. While, minimum field capacity of effective field capacity of 0.418 $\mathrm{fed} / \mathrm{h}$ was recorded at forward speed of $1.88 \mathrm{~km} / \mathrm{h}$, hill spacing of $0.15 \mathrm{~m}$ and planting depth of $15 \mathrm{~cm}$.

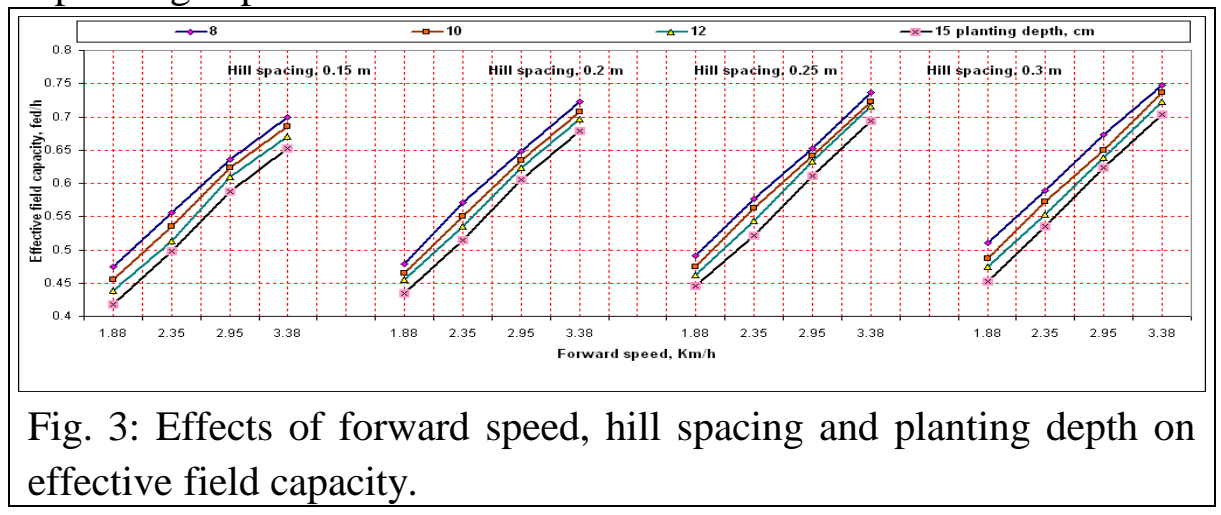

\section{Field efficiency}

Fig. 4 indicated that, field efficiency was decreased with increasing forward speed and planting depth. While, it was increased with increasing hill spacing. Also, results showed that, maximum field efficiency of $83.1 \%$ was recorded at forward speed of $1.88 \mathrm{~km} / \mathrm{h}$, hill spacing of $0.3 \mathrm{~m}$ and planting depth of $8 \mathrm{~cm}$. While, minimum field efficiency of $57.7 \%$ was recorded at forward speed of $3.38 \mathrm{~km} / \mathrm{h}$, hill spacing of $0.15 \mathrm{~m}$ and planting depth of $15 \mathrm{~cm}$.

\section{Seed scattering}

The effect of forward speed, hill spacing and planting depth on both longitudinal and transverse scattering are shown in Figs. 5 and 6. Results noticed that, increasing forward speed from 1.88 to $3.38 \mathrm{~km} / \mathrm{h}$ and hill spacing from 0.15 to $0.30 \mathrm{~m}$ tends to increase both of longitudinal and transverse scattering. While, increasing planting depth from 8 to $15 \mathrm{~cm}$ led to decrease both of longitudinal and transverse scattering. Also results showed that, maximum both of longitudinal and transverse scattering were 0.042 and $0.03 \mathrm{~m}$ recorded at forward speed of $3.38 \mathrm{~km} / \mathrm{h}$, hill spacing of $0.3 \mathrm{~m}$ and planting depth of $8 \mathrm{~cm}$. While, minimum both of longitudinal and transverse scattering were 0.016 and $0.01 \mathrm{~m}$ recorded at forward speed of $1.88 \mathrm{~km} / \mathrm{h}$, hill spacing of $0.15 \mathrm{~m}$ and planting of 15 $\mathrm{cm}$. 


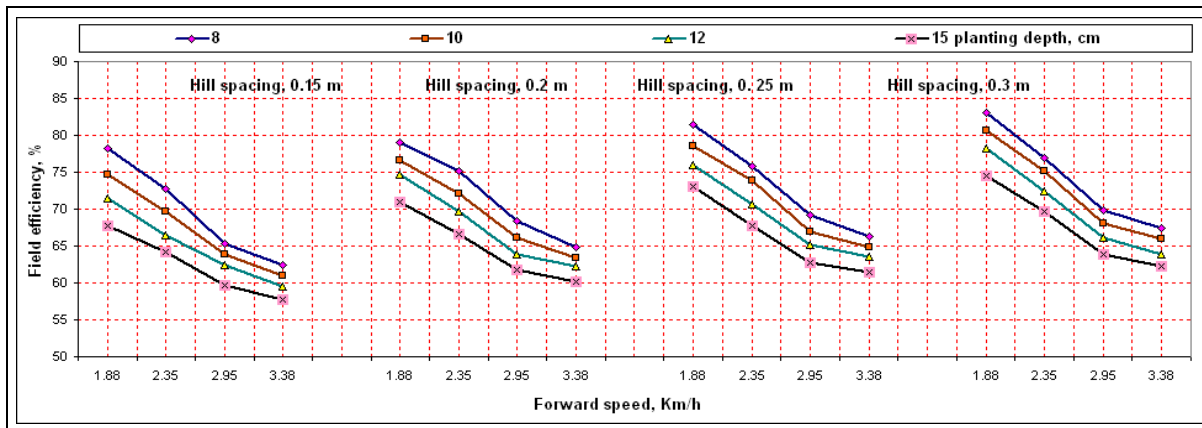

Fig. 4: Effects of forward speed, hill spacing and planting depth on field efficiency.

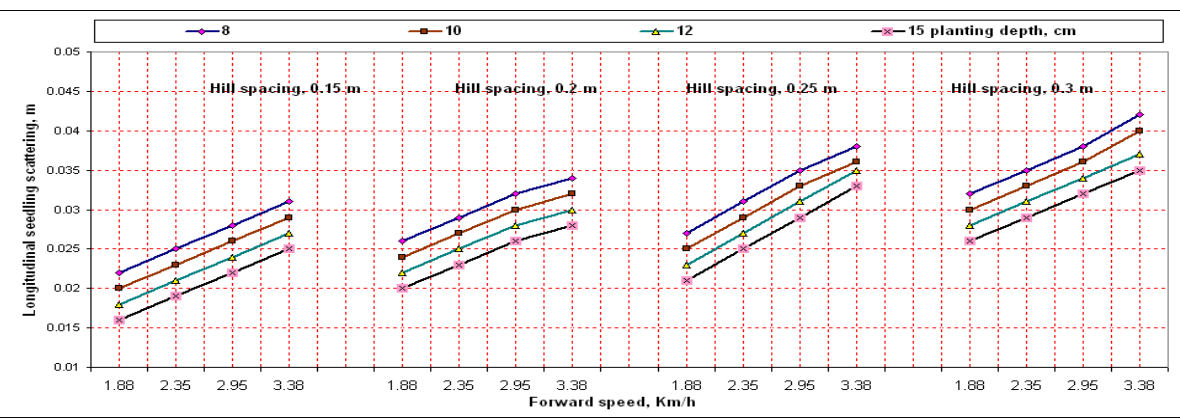

Fig. 5: Effects of forward speed, hill spacing and planting depth on longitudinal seed scattering.

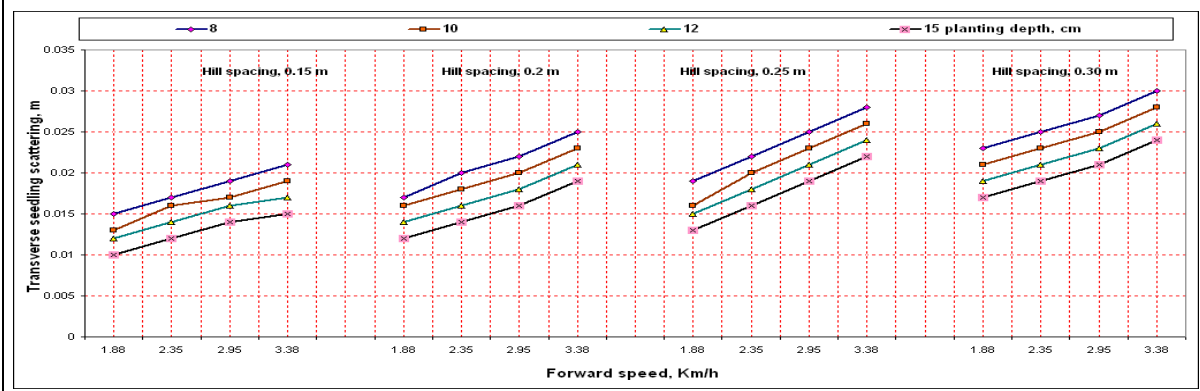

Fig. 6: Effects of forward speed, hill spacing and planting depth on transverse Seed scattering.

\section{Slippage ratio}

Fig. 7 demonstrated that, hill spacing did not affect the slip ratio, while it was increased with increasing both of forward speed and planting depth. Such as, with increasing forward speed from 1.88 to $3.38 \mathrm{~km} / \mathrm{h}$ at planting depth of $8 \mathrm{~cm}$, slip ratio was increased from 7.42 to $9.87 \%$ $(+33.01 \%)$. Also, by increasing planting depth from 8 to $15 \mathrm{~cm}$ at 
forward speed of $1.88 \mathrm{~km} / \mathrm{h}$, slip ratio was increased from 7.42 to $8.2 \%$ $(+10.51 \%)$. Results noticed also that, maximum of slip ratio was $10.56 \%$ recorded at forward speed of $3.38 \mathrm{~km} / \mathrm{h}$ and planting depth of $15 \mathrm{~cm}$. While, minimum of slip ratio was $7.42 \%$ recorded at forward speed of $1.88 \mathrm{~km} / \mathrm{h}$ and planting depth of $8 \mathrm{~cm}$.

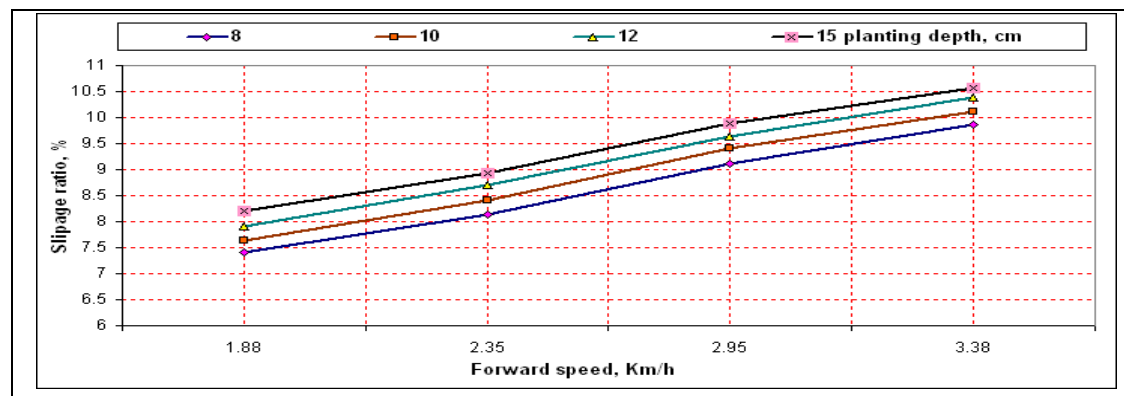

Fig. 7: Effects of forward speed, hill spacing and planting depth on slippage ratio.

\section{Seedling miss index}

Results found that, increasing forward speed or increasing hill spacing and planting depth led to decrease seedling miss index while increasing hill spacing led to increase seedling miss index as shown in Fig. 8. Results saw also that, minimum seedling miss index of $1.7 \%$ was recorded at forward speed of $3.38 \mathrm{~km} / \mathrm{h}$, hill spacing of $0.15 \mathrm{~m}$ and planting depth of $15 \mathrm{~cm}$.

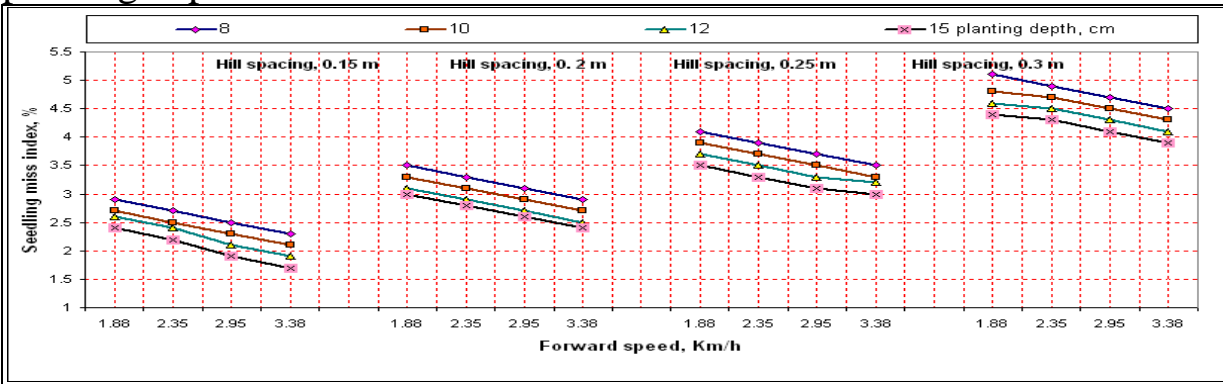

Fig. 8: Effects of forward speed, hill spacing and planting depth on seedling miss index.

\section{Seedling multiple index}

Results indicated that, seedling multiple index was increased with increasing forward speed while, it was decreased with increasing both of 
hill spacing and planting depth as shown in Fig. 9. Results noticed that also, minimum seedling multiple index of $0.9 \%$ was recorded at forward speed of $1.88 \mathrm{~km} / \mathrm{h}$, hill spacing of $0.30 \mathrm{~m}$ and planting depth of $15 \mathrm{~cm}$. And maximum value of seedling multiple index of $4.3 \%$ was recorded at forward speed of $3.38 \mathrm{~km} / \mathrm{h}$, hill spacing of $0.15 \mathrm{~m}$ and planting depth of $8 \mathrm{~cm}$.

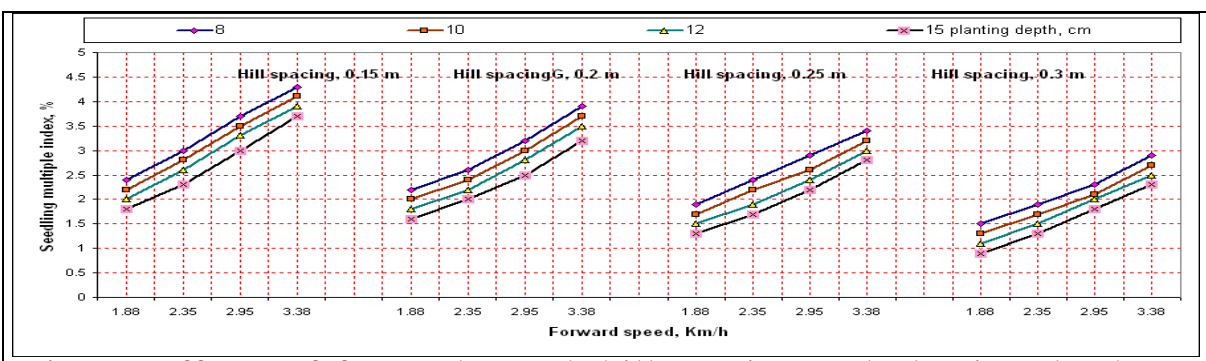

Fig. 9: Effects of forward speed, hill spacing and planting depth on seedling multiple index.

\section{The quality of feed index}

Fig. 10 indicates that, the quality of feed index was increased with increasing both of hill spacing and planting depth while it was decreased with increasing forward speed. From previous results, it can be noticed that hill spacing was very important factor affected on the quality of feed index. Also, minimum value of the quality of feed index of $89.6 \%$ was recorded with forward speed of $3.38 \mathrm{~km} / \mathrm{h}$, hill spacing of $0.15 \mathrm{~m}$ and planting depth of $8 \mathrm{~cm}$. While, maximum value of the quality of feed index was $97.3 \%$ recorded with forward speed of $1.88 \mathrm{~km} / \mathrm{h}$, hill spacing of $0.30 \mathrm{~m}$ and planting depth of $15 \mathrm{~cm}$.

\section{Productivity}

Results indicated that, final crop productivity was increased with increasing both of hill spacing and planting depth while it was decreased with increasing forward speed as shown in Fig. 11. From previous results, it can be noticed that, hill spacing was very important effective factor on productivity. Also, maximum productivity of $7.61 \mathrm{kantar} / \mathrm{fed}$ recorded at forward speed of $1.88 \mathrm{~km} / \mathrm{h}$, hill spacing of 0.25 and planting depth of $8 \mathrm{~cm}$. 


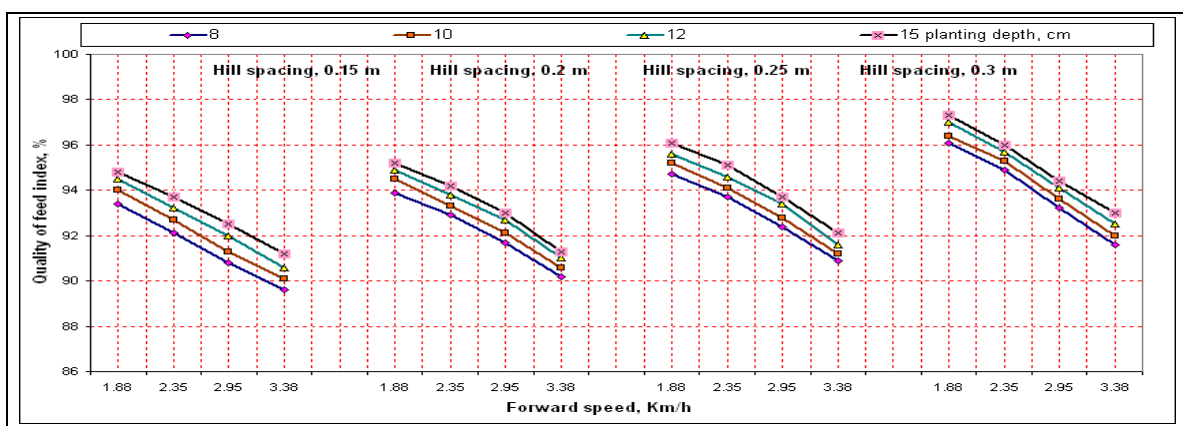

Fig. 10: Effects of forward speed, hill spacing and planting depth on the quality of feed index.

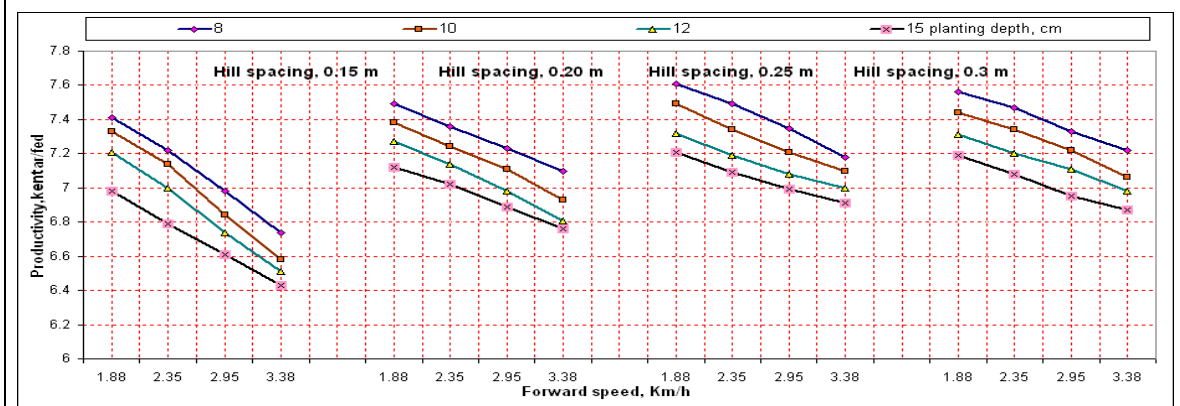

Fig. 11: Effects of forward speed, hill spacing and planting depth on productivity.

\section{Losses in productivity due to missing seedling}

Results indicated that, losses in productivity due to missing seedling was increased by increasing both of forward speed and hill spacing. While, it was decreased with increasing planting depth as shown in Fig. 12. Results found too that, minimum losses in productivity due to missing seedling of $0.132 \mathrm{kantar} / \mathrm{fed}$ was recorded at forward speed of $1.88 \mathrm{~km} / \mathrm{h}$, hill spacing of $0.30 \mathrm{~m}$ and planting depth of $15 \mathrm{~cm}$. From the above it is clear that, forward speed was more influential factor on losses in productivity due to missing seedling.

\section{Specific fuel consumption}

Results as shown in Fig. 13 represent the effect of forward speed, hill spacing and planting depth on specific fuel consumption. Where, specific fuel consumption was had inversely proportional with increasing both of hill spacing and planting depth. While, it was had directly proportional with increasing forward speed. From previous, results indicated that, planting depth was very important factor affected on specific fuel 
consumption also, minimum specific fuel consumption of $0.511 \mathrm{~L} / \mathrm{kW} . \mathrm{h}$ was recorded at forward speed of $1.88 \mathrm{~km} / \mathrm{h}$, hill spacing of $0.30 \mathrm{~m}$ and planting depth of $15 \mathrm{~cm}$.

\section{Operation and Criterion function cost}

Fig. 14 illustrate that, total operation cost was decreased with increasing both of forward speed and hill spacing. While it was increased with increasing planting depth. From a above it is clear that, forward speed has been more influential factor on operation cost. On the other hand, Fig. 14 illustrates the effect of forward speed, hill spacing and planting depth on criterion function cost. Where, it was increased with increasing forward speed, while it was decreased with increasing both of hill spacing and planting depth. From above it is clear that, forward speed was more influential factor on criterion function cost. minimum value of operation cost of $45.98 \mathrm{~L}$.E/fed was recorded at forward speed of 3.38 $\mathrm{km} / \mathrm{h}$, hill spacing of $0.25 \mathrm{~m}$ and planting depth of $8 \mathrm{~cm}$. While, minimum value of criterion function cost was 196.78 L.E/fed was recorded at forward speed of $1.88 \mathrm{~km} / \mathrm{h}$, hill spacing of $0.25 \mathrm{~m}$ and planting depth of $15 \mathrm{~cm}$, respectively. Also, from previous results by means of crossing curves of operation cost and criterion function cost it can be noticed that, the optimum operation condition was at forward speed of $2.95 \mathrm{~km} / \mathrm{h}$, planting depth of $8 \mathrm{~cm}$ and hill spacing of $0.25 \mathrm{~m}$.

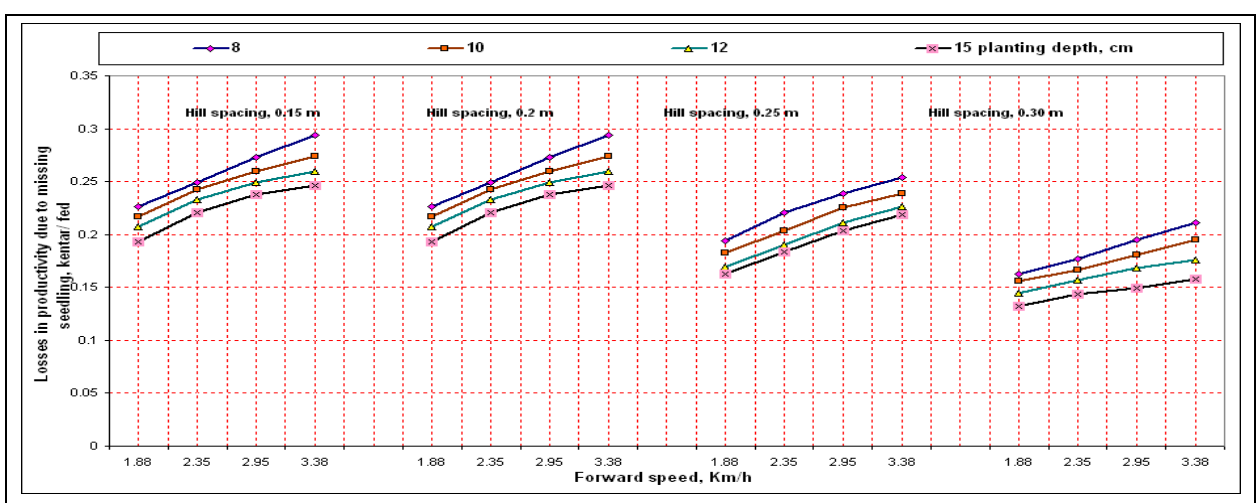

Fig. 12: Effects of forward speed, hill spacing and planting depth on losses in productivity due to missing seedling. 


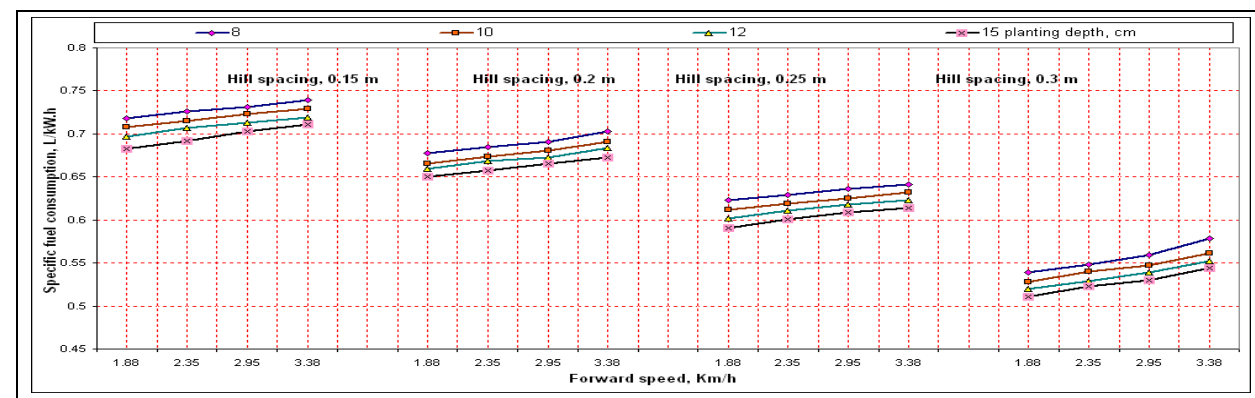

Fig. 13: Effects of forward speed, hill spacing and planting depth on specific fuel consumption.

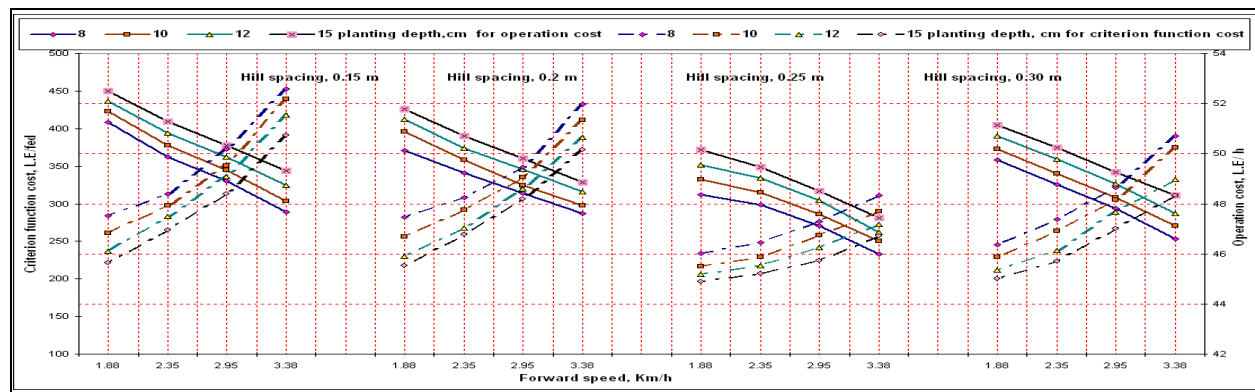

Fig. 14: Effects of forward speed, hill spacing and planting depth on operation cost and criterion function cost.

\section{Characteristics of seed cotton:}

Table 4 listed the technical properties of raw seed cotton resulting from seedling transplanter and manual planting method. It was obvious that the seedling transplanting was produced the quality characteristics of 2.5 and $50 \%$ span fiber length, fiber length uniformity ratio and fiber strength.

Table 4 : Seed cotton technical properties resulting from transplanting seedling and manual planting method.

\begin{tabular}{|l|c|c|}
\hline $\begin{array}{l}\text { Seed cotton technical } \\
\text { properties. }\end{array}$ & $\begin{array}{c}\text { Transplanting seedling } \\
\text { method }\end{array}$ & Manual planting \\
\hline $2.5 \%$ span length, $\mathrm{mm}$ & 32.5 & 32.3 \\
\hline $50 \%$ span length, $\mathrm{mm}$ & 16.7 & 15.5 \\
\hline Length uniformity, $\%$ & 49.8 & 47.9 \\
\hline Microniere reading, unit & 5.24 & 5.26 \\
\hline Color yellowness(+b) & 7.5 & 7.4 \\
\hline Color reflectance(rd) & 73.7 & 74.1 \\
\hline Cotton strength, g/tex & 29.5 & 28.9 \\
\hline Cotton elongation, \% & 8.4 & 8.4 \\
\hline
\end{tabular}


While, manual planting gave high amount of color reflectance and microniere reading but in general, results illustrated smallness differences between the two different planting method.

When transplanting mechanical regularity of the distances between the seedlings were enables plant growth better than manual transplanting where regularity was allowed to plant its needs of light and space necessary for the growth of more than transplanting manual, which was showing its effect on natural qualities of the output of cotton.

\section{CONCLUSION}

The characteristics conclusion could be summarized as follow:-

1- The optimum operation condition for modify transplanter was at forward speed of $2.95 \mathrm{~km} / \mathrm{h}$, planting depth of $8 \mathrm{~cm}$ and hill spacing of $0.25 \mathrm{~m}$ the optimum point for the operation of the machine determine where that was the point at which then have the lowest amount of the cost of the machine and the lowest value of the criterion function cost.

2- Maximum of effective field capacity was $0.739 \mathrm{fed} / \mathrm{h}$ recorded at forward speed of $3.38 \mathrm{~km} / \mathrm{h}$, hill spacing of $0.30 \mathrm{~m}$ and planting depth of $8 \mathrm{~cm}$. While, maximum of field efficiency was $83.1 \%$ recorded at forward speed of $1.88 \mathrm{~km} / \mathrm{h}$, hill spacing of $0.30 \mathrm{~m}$ and planting depth of $8 \mathrm{~cm}$.

3- Minimum of longitudinal and transverse scattering were 0.016 and 0.10 $\mathrm{m}$ recorded at forward speed of $1.88 \mathrm{~km} / \mathrm{h}$, hill spacing of $0.15 \mathrm{~m}$ and planting depth of $8 \mathrm{~cm}$.

4- Minimum of slip ratio was $7.42 \%$ recorded at forward speed of 1.88 $\mathrm{km} / \mathrm{h}$, hill spacing of $0.15 \mathrm{~m}$ and planting depth of $8 \mathrm{~cm}$.

5- Seedling miss index and seedling multiple index were increased with increasing both of forward speed and hill spacing. While, its were decreased with increasing planting depth.

6- The quality of feed index was increased with increasing all of forward speed, hill spacing and planting depth.

7- Maximum of productivity was $7.61 \mathrm{kantar} / \mathrm{fed}$ recorded at forward speed of $1.88 \mathrm{~km} / \mathrm{h}$, hill spacing of $0.25 \mathrm{~m}$ and planting depth of $8 \mathrm{~cm}$.

8- Specific fuel consumption was decreased with increasing of forward speed and planting depth. While, it was increased with increasing hill spacing. 
9- operation cost at the optimum operation condition was $47.12 \mathrm{~L} . \mathrm{E} / \mathrm{fed}$. While, criterion function cost was 276.01 L.E/fed.

\section{REFERENCES}

ASAE Standards. (1989). Agricultural Machinery Management ASAE standards, Ep 391, 1, and 230, 4.

Awady, M.N.(1992). Farm machines. Textbook, Col. of Agric. Ain Shams Univ.; $120 \mathrm{p}$.

Dong, H.Z.; D.M., Zhang; W., Tang; W.J., Li and Z.H., Li (2005). Effects of planting system, plant density and flower removal on yield and quality of hybrid seed in cotton. Field Crops Res. 93, 7484.

El-Fowal, Y.A.A. (1996). Astudy on possibilities of mechanical wheat transplanting. M.Sc. Th., Fac. Agric., Al-Azhar Univ., Egypt.

EL-Sayed. E.A.S. (1992). Effect of transplanting on growth and yield of cotton. M.Sc. Th., Tanta Univ., Egypt.

El-Sahrigi, A.F.; A.S., Kamel and S.I., El-Khatib (2001). A study on mechanization of cotton transplanting. Egypt J. Agric. Res. 79, 740-756.

El-Sahrigi, A.F.; M.M., Ibrahim and K. S., Hegazy. (1991). The possibility of Utilizing mechanical planting of onion crop under Egyptian Conditions, Misr J. Agric. Eng. 8(3): 162-171.

Greer, N.W.; K.S., Mclean; and J.W., Kloepper (2003). Potential of cotton transplants and rhizobacteria to shorten the growing season. In: Proceedings of the Beltwide Cotton Conference, pp. 13-16.

Hammed , S.A.; M.A., Ali; A.M. khalifa and A.M., Ismail (1993). A manual Feeding rice transplanter. J. Agric. Sci., Mansoura Univ. 8(1): $72-80$.

Harb, S.K.; H.A., Abdell-Mawal and G.M., Salama (1993). Comparison between mechanichal and manual transplanting of tomato. Minia J. of Agric. Res. Vol. 15 (1): 361-375.

Hassan, I.S.M.; H.B., Abou-Tour and S.M., Seyam (2006). Evaluation and stability parameters of the hybrid G.84 (G.74×G.68) and four Egyptian extra-long staple cotton cultivars grown at North Delta, Egypt. J. of Appl. Sci. 21(8):59-73. 
Hunt, D. (1983). Farm power and machinery management. $8^{\text {th }}$ Ed. Iowa state Univ., Press Ames, Iowa, USA: 364-368.

Karve, A.D. (2003). High yield of rain fed cotton through transplanting. Curr. Sci. 84, 974-975.

Konosuke TSUGA, (2000). Development of fully automatic vegetable transplanter. JARQ, 34, 21-28.

Salama, G.M.; A.M., Youssef and S.S.A., Farge (1995). Tomato plant growth and productivity as affected by method transplanting. Vegetable Res. Section. Hort. Res. Inst.. Agric. Res. Center. Cairo, Egypt,22(2): 109-115.

Sales, E.; R., Kanhonou and C., Baixauli (2006). Sowing date, transplanting, plant density and nitrogen fertilization affect indigo production from Isatis species in a Mediterranean region of Spain. Ind. Crops Prod. 23, 29-39.

Sherif, M.N.; M.S.M, Selim and A.S., Kamel (1995). Studies on some factors affecting seed and fiber properties of transplanted cotton. Ann. Agric. Sci. Moshtohor, 33, 647-657.

Srivastava, A.K; C.E.Goering and R.P.Rohrbach (1994). Engineering principles of Agricultural machines. ASAE textbook No. 6 published The ASAE

Stell, R.G. and S.H., Torrie (1980). Principles and procedures of statistics. McGraw- Hill Company, N.Y.

Suliman,A.E.; G.E., Nasr and W.M., Adawy (1993). A study on the effect of different systems of tillage on physical properties of the soil. Misr J.Ag.Eng.,10(2):169-189.

الملخص العربي

تعديل آلة شتل نصف اوتوماتيكية لتناسب شتّل القطن

د/عاطف عزت اليمانى* ، د/ محمد عبد اللة خضير* و د/ محمد عبد اللة إبراهيم حسن* لنعل

يعاني محصول القطن المصري من مشـاكل عديدة أهمها زيادة تكاليف الإنتاج ويشغل القطن

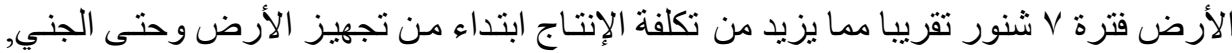

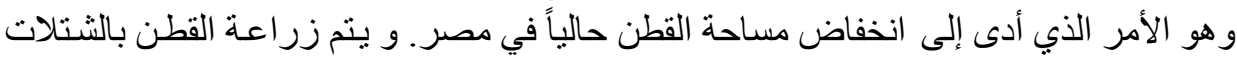
بهدف تقصير موسم نمو القطن لتوفير أو تقليل تكلفة الإنتاج و إمكانية زر اعة القية القطن بعد محاصيل شتوية في نفس المساحة مثل القمح او البرسير.

*معها بحوث الهندة الزراعيةـ الاقى -الجيزة ـ مصر 
و قد تم تجريب زر اعة القطن بشتالة الخضـر التقليديـة و لكنها لم تعطى نتائج جيدة نظر الكبر

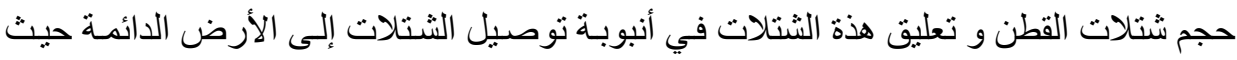

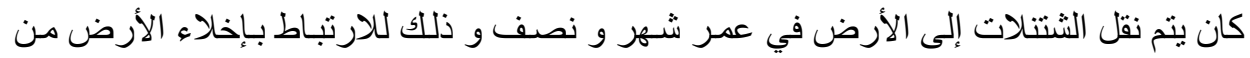

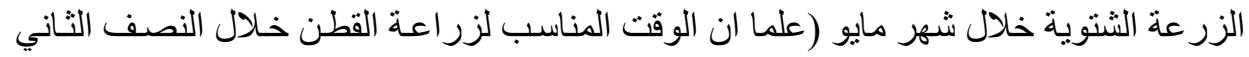

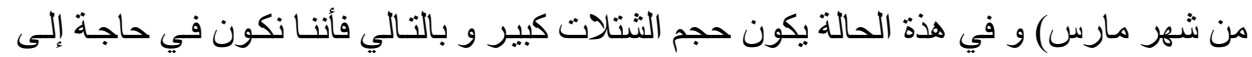

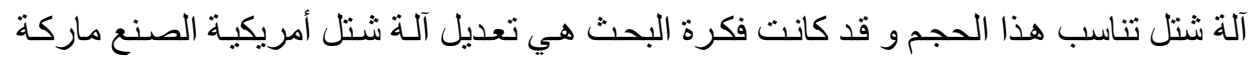
Holland عبارة عن سير دو ار بركب على محيطة عدد عشرون وحدة تلقيم يتم وضـع الشتلات بها فتنقلها

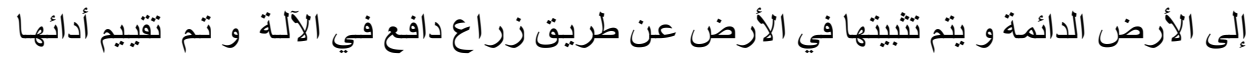

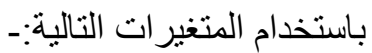

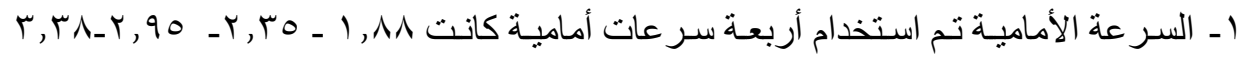
كم/س.

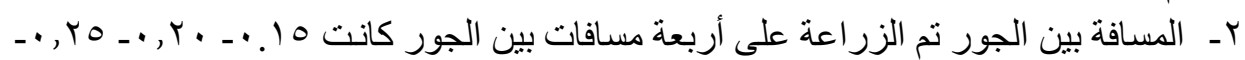
• • • م. •

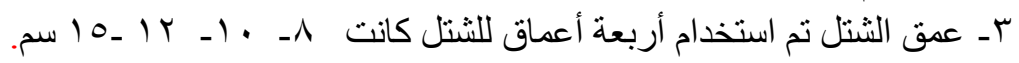

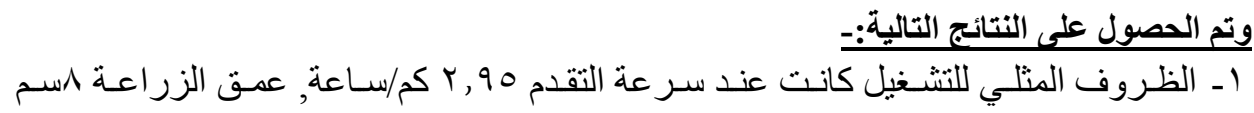

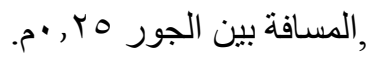

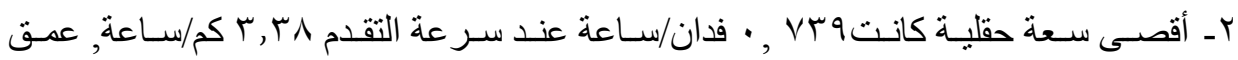

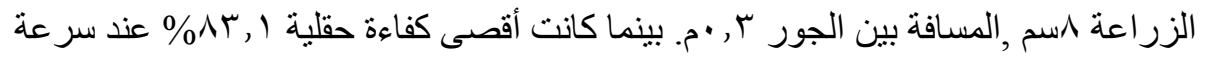

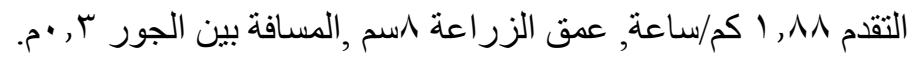

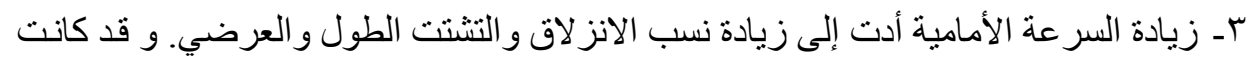

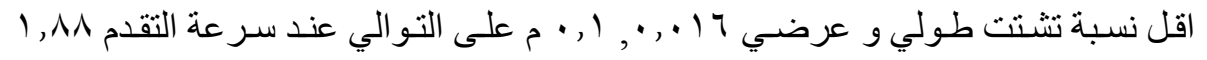

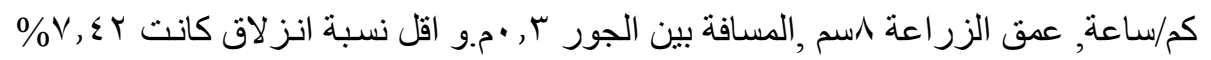

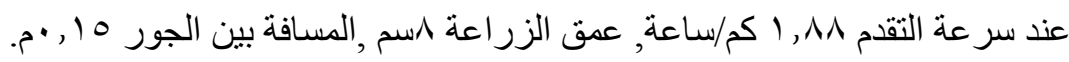

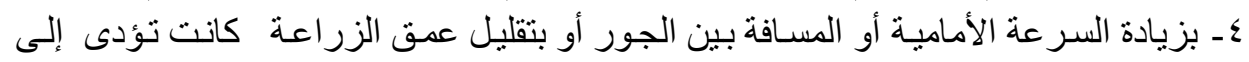

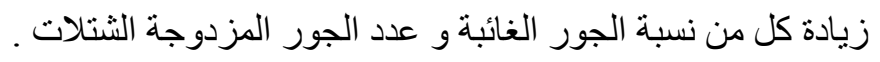

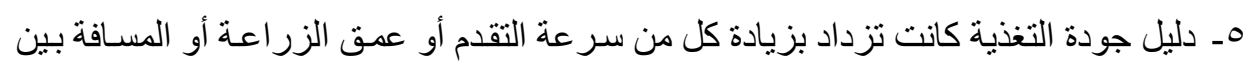
الجور.

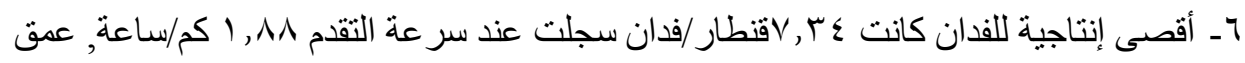

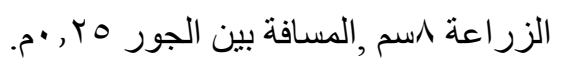

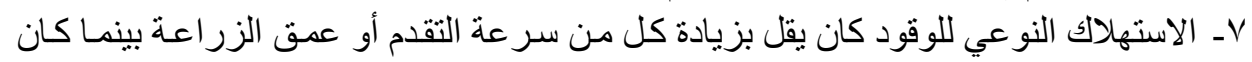

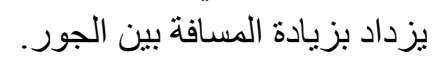

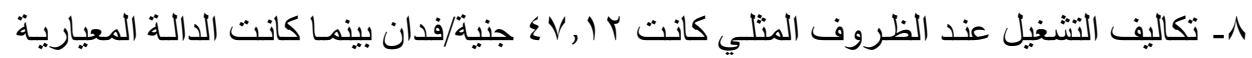

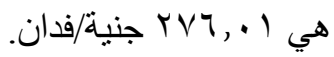

